\title{
Bayesian assessment of two competitive enzyme-linked immunosorbent assays for the detection of bovine viral diarrhoea virus antibodies in bovine sera
}

\author{
C. Saegerman ${ }^{(1) *}$, C. Quinet ${ }^{(2)}$, G. Czaplicki ${ }^{(2)} \&$ F. Dal Pozzo ${ }^{(1)}$ \\ (1) Research Unit in Epidemiology and Risk Analysis applied to Veterinary Sciences (UREAR-ULg), Fundamental \\ and Applied Research for Animal and Health (FARAH) Centre, Faculty of Veterinary Medicine, University of \\ Liege, 20, Boulevard de Colonster, 4000 Liege, Belgium \\ (2) Animal Health Department, Regional Association for Livestock Health and Identification (ARISA), Allée des \\ Artisans 2, 5590 Ciney, Belgium \\ *Corresponding author: claude.saegerman@uliege.be
}

\begin{abstract}
Summary
Infections due to bovine viral diarrhoea virus (BVDV) are endemic in most cattleproducing countries throughout the world and bovine viral diarrhoea is considered a transboundary disease. The key elements of a BVDV control programme are vaccination, biosecurity, elimination of persistently infected (PI) animals and surveillance. The aim of this study was to assess the sensitivity (Se) and the specificity (Sp) of two commercial competitive enzyme-linked immunosorbent assays (ELISAs) based on selected immune-dominant BVDV proteins: the nonstructural protein NS3 (p80) and the recombinant envelope glycoprotein E0 (Erns). Both tests were used on individual serum samples from randomly sampled young bovines in southern Belgium in order to detect specific BVDV antibodies. The Se and Sp were assessed using a Bayesian approach and were estimated, respectively, at $97.2 \%$ (with 95\% credibility interval [Cr I]: 95.1-99.8) and $98.7 \%$ (95\% Cr I: 96.6-99.9) for the first test and 95.8\% (95\% Cr I: 91.1-99.7) and $96.1 \%$ (95\% Cr I: 95.1-97.7) for the second test. The results obtained with the two tests were not significantly different. In addition, using both ELISAs, the current BVDV exposure among young bovines in southern Belgium was estimated at $23.3 \%(95 \%$ Cr I: 20.6-26.2). Combining virological testing of all newborns to detect PI animals with regular serological testing of young stock using ELISAs is recommended in the surveillance of BVDV.
\end{abstract}

\section{Keywords}

Assessment - Bayesian framework - Belgium - Bovine viral diarrhoea virus - Cattle Diagnosis - ELISA - Enzyme-linked immunosorbent assay - Sensitivity - Specificity.

\section{Introduction}

Infections with bovine viral diarrhoea virus (BVDV) are endemic in most cattle-producing countries throughout the world (1). The pathogenesis of BVDV is complex, with pre-, mid- and post-gestation infections leading to different outcomes. Infection of the dam during pregnancy can result in foetal infection, which may lead to embryonic death, teratogenic effects, or the birth of persistently infected (PI) calves. These PI animals shed BVDV throughout their lives and are of primary importance in the maintenance of the virus in the environment or on the farm (2).
Bovine viral diarrhoea virus infection causes financial losses estimated at between EUR 21 and 135 per cow, mostly associated with reproductive disorders and the occurrence of PI animals (3). The virus is endemically present in numerous countries in addition to Belgium. Consequently, a number of BVDV mitigation and eradication schemes are implemented around the world. These schemes are based on four major elements: vaccination, biosecurity, the elimination of PI animals and surveillance. Surveillance is mainly based on the verification of the absence of BVDV circulation at the individual level or the herd level using antigen and/or antibody enzyme-linked immunosorbent assays (ELISAs) $(1,4,5)$. 
Since bovine virus diarrhoea (BVD) was recognised as a unique disease complex, many different diagnostic methods have been used to detect BVDV itself, or the immune response to BVDV (6). The reference test for detection of antibodies against BVDV is the virus neutralisation test (VNT) (7). This is a sensitive and specific assay but is cell-culture-dependent, and labour intensive in comparison with an ELISA. Therefore, the latter is usually preferred when a large sample throughput is required (8). Conventional ELISAs based on BVDVinfected cells have disadvantages because BVDV produces low levels of proteins in tissue culture and it is difficult to purify because of its cell association. Recombinant antigens provide an alternative for the reliable detection of BVDV antibodies in bovine sera (9). The most immunogenic proteins of BVDV are the envelope glycoproteins E0 (Erns) and E2, and the non-structural protein NS3 (previously named p80) (9). However, the E0 and NS3 proteins are more conserved among BVDV strains and the NS3 protein is essential for viral replication (in wild-type BVDV or modified-live BVDV vaccines) (10, 11). In addition, the agreement between ELISAs for the detection of pestivirus antibodies directed against conserved epitopes on NS3, E0 or E2 and the VNT (the World Organisation for Animal Health [OIE] reference test [12]) is considered to be excellent $(6,13,14,15)$.

The aim of this study was to assess the sensitivity (Se) and the specificity (Sp) of two commercial competitive ELISAs using a Bayesian approach. Individual serum samples from cattle in southern Belgium were used to detect antibodies produced against the recombinant envelope glycoprotein E0 and the non-structural protein NS3. In addition, the current seroprevalence of BVDV in southern Belgium was estimated among young bovines.

\section{Materials and methods}

\section{Study area and sample collection}

The study was conducted in the southern part of Belgium, primarily for the assessment of the Se and $\mathrm{Sp}$ of the ELISAs, in January and February 2014. This area is characterised by the presence of dairy and beef cattle ( $n=11,160$ herds $)$. A cross-sectional study was performed using serum samples randomly collected by herd veterinarians during a Belgian monitoring programme. This monitoring programme aimed to detect the circulation of different pathogens in bovines aged between six and 12 months (regardless of gender and breed) in 450 randomly selected herds. This age category was selected to avoid the detection of maternal antibodies. A maximum of ten randomly selected animals was sampled per herd in this specific age category. In some herds, no animals between six and
12 months of age were present at the time of sampling. In southern Belgium, the total number of bovines included in this age category is 140,000 . In order to evaluate the current exposure to BVDV in young animals in this area and with an expected BVDV seroprevalence of $35 \%$ (due to natural infection and/or vaccination), an accepted error of 3\% and a level of confidence of $95 \%(16,17)$, the necessary sample size was calculated to be $n=972$. The current study used a larger sample size. In total, 988 blood sera specimens were randomly sampled from 164 herds in southern Belgium.

\section{Competitive enzyme-linked immunosorbent assays}

Two commercially available competitive ELISAs were used according to the producer's instructions (Bio-X Diagnostic, Rochefort, Belgium). In the first ELISA, 96well microtitration plates were coated with BVDV NS3 non-structural protein (BIO K 230, Bio-X Diagnostic). In the second test, 96-well microtitration plates were coated with the recombinant BVDV E0 protein (BIO K 283, Bio-X Diagnostic).

The optical densities (ODs) of the positive and negative control sera (OD pos. and OD neg.) and those of all the tested samples (OD samples) were measured. The percentage of inhibition for each tested sample and the positive serum were calculated by means of formulae [1] and [2] below:

$\%$ inhibition sample $=\frac{(\text { OD neg. }- \text { OD sample })}{\text { OD neg. }} \times 100$

$\%$ inhibition positive $=\frac{(\text { OD neg. }- \text { OD pos. })}{\text { OD neg. }} \times 100$

According to the manufacturer, each test was validated if the OD neg. - OD pos. was $>0.7$. The cut-off value was fixed as a $\%$ inhibition positive of $>50 \%$.

\section{Estimation of true prevalence, test sensitivity and test specificity}

A Bayesian approach was used to evaluate the performance of the NS3- and E0-competitive ELISAs by estimating Se and Sp as previously described $(18,19,20)$. The results obtained for a given animal using the two tests were considered conditionally dependent. The Bayesian model was developed by taking into account this correlation in exposed animals (positive for BVDV-specific antibodies) as well as in unexposed animals (negative for BVDV-specific antibodies) (20). Furthermore, in the applied Bayesian model, field data (obtained from the results of both ELISAs on the collected bovine sera) and prior information obtained from the literature were included. 
In particular, the following available prior information was used: BVDV seroprevalence in Belgium (0.20-0.40) (16), Se and Sp of the NS3-competitive ELISA (Se: [0.95-1]; Sp: [0.95-1]), Se and Sp of the E0-competitive ELISA (Se: [0.60-1]; Sp: [0.95-1]) $(2,9,21)$, with covariance as previously described (19). The model was run in Winbugs ${ }^{\circledR}$ (22) (see Appendix 1). Additional calculations during the Bayesian analysis were done in $\mathrm{R}$ software/environment (R-3.0.1, R Foundation for Statistical Computing, www.rproject.org/) (23). Three parameters were monitored during the analysis: the deviance information criterion (DIC), the effective number of estimated parameters (pD) and the Bayesian P-value. As previously described (20), the DIC and the Bayesian P-value were used to check conflicts between prior information and current ELISA results. The impact of the constraints was assessed using the $\mathrm{pD}$ of the model. The model used three parallel Markov chains, with a burnin of 10,000 iterations and an additional 90,000 iterations to obtain the posterior distributions. In order to explore the convergence of the model, trace plots were simultaneously combined with autocorrelation plots. If the trace plot showed good mixing and the autocorrelation plot showed very little or no correlation among samples, convergence could be claimed. In situations where autocorrelations were still high after the first few lags in the chains, thinning was applied. The thinning coefficient was determined by the number of lags at which the autocorrelations significantly dropped to zero. Additionally, the Brooks-Gelman-Rubin (BGR) statistical test for convergence was used. A good fit of the model was shown by a Bayesian $P$-value around 0.5 and going towards zero under strict constraints $(18,20)$.

\section{Assessment of agreement between the tests}

A concordance analysis was performed to assess the agreement of the two tests. The level of agreement was expressed in terms of indices of positive and negative agreement (24), respectively the observed agreement proportion for positive and negative test results (see formulae [3] and [4]). Confidence intervals were calculated according to the method described by Graham and Bull (25). Calculations of the different parameters were done using R. Using a two-by-two contingency table (Table I), the indices of positive agreement $\left(P_{\text {pos }}\right)$ and negative agreement $\left(P_{\text {neg. }}\right)$ were, respectively:

$$
P_{\text {pos. }}=\frac{2 a}{2 a+b+c}
$$

and $P_{\text {neg. }}=\frac{2 d}{2 d+b+c}$

where $P_{\text {pos. }}$ and $P_{\text {neg. }}$ are, respectively, the indices of positive agreement and negative agreement (24); $a, b, c$ and $d$ are given in Table I.
Table I

Contingency table showing results for non-structural protein NS3-blocking enzyme-linked immunosorbent assay (ELISA) (T1) and the envelope glycoprotein EO-blocking ELISA (T2)

\section{A) Codification}

\begin{tabular}{|c|c|c|c|c|}
\hline & \multicolumn{4}{|c|}{ T1 } \\
\hline & & Pos. & Neg. & Total \\
\hline \multirow{3}{*}{ T2 } & Pos. & $a$ & $b$ & $a+b$ \\
\hline & Neg. & $c$ & $d$ & $c+d$ \\
\hline & Total & $a+c$ & $b+d$ & $\boldsymbol{N}$ \\
\hline
\end{tabular}

\section{B) Observation}

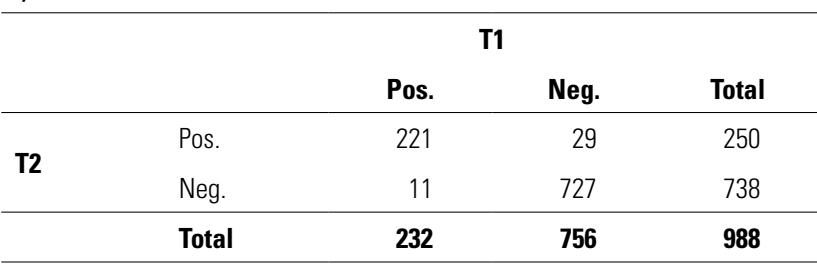

$N$ : total number of samples tested by the two diagnostic tests $(a+b+c+d)$

Neg.: negative result

Pos.: positive result

\section{Prior sensitivity analysis}

Using the Bayesian model with conditional dependence between tests, the parameter estimates were found to be varying together with the prior distributions (19). Therefore, in order to assess the influence of the proposed prior distributions on the estimated parameters, as an Se analysis was performed using non-informative priors $(19,26)$. In addition, for each set of alternative prior distributions considered for the parameters, the model was run with the same number of chains and similar diagnostics were performed.

\section{Results}

\section{Serological results}

The two-by-two contingency table (Table IA) cross-classified the test results of the 988 samples based on both the NS3-competitive ELISA (test 1, T1) and the E0-competitive ELISA (test 2, T2), resulting in the following classes: $a=221, b=29, c=11$ and $d=727$ (Table IB). A total of $232(23.5 \%)$ sera tested positive for $\mathrm{Tl}$ whereas 250 (25.3\%) were found positive for T2. Both tests gave the same results on 948 sera $(96.0 \%)$.

The general tendency of the separation of BVDV-exposed and unexposed animals detected by each competitive ELISA was determined by the frequency histograms (Figs $1 \mathrm{~A}$ and $1 \mathrm{~B}$ ) and the corresponding kernel densities 
(Figs 1C and 1D). Therefore, the two subpopulations of BVDV-exposed and unexposed animals were well separated by both competitive ELISAs, considering the cut-off of 50\% of inhibition. However, the subpopulations were more clearly separated by the E0-blocking ELISA (Figs 1B and 1D).

\section{Indices of agreement between tests}

The cross-classified test results ( $a=221, b=29, c=11$ and $d=727$ ) were used to calculate the indices of agreement between the assays. The NS3- and E0-competitive ELISAs gave the same results on $91.7 \%$ of the positive results $\left(P_{\text {pos. }}\right)$, whereas the agreement on negative results $\left(P_{\text {neg. }}\right)$ was estimated to be $97.3 \%$. The $95 \%$ confidence intervals ranged from $88.9 \%$ to $94.0 \%$ and $96.4 \%$ to $98.1 \%$, respectively, for $P_{\text {pos. }}$ and $P_{\text {neg. }}$.
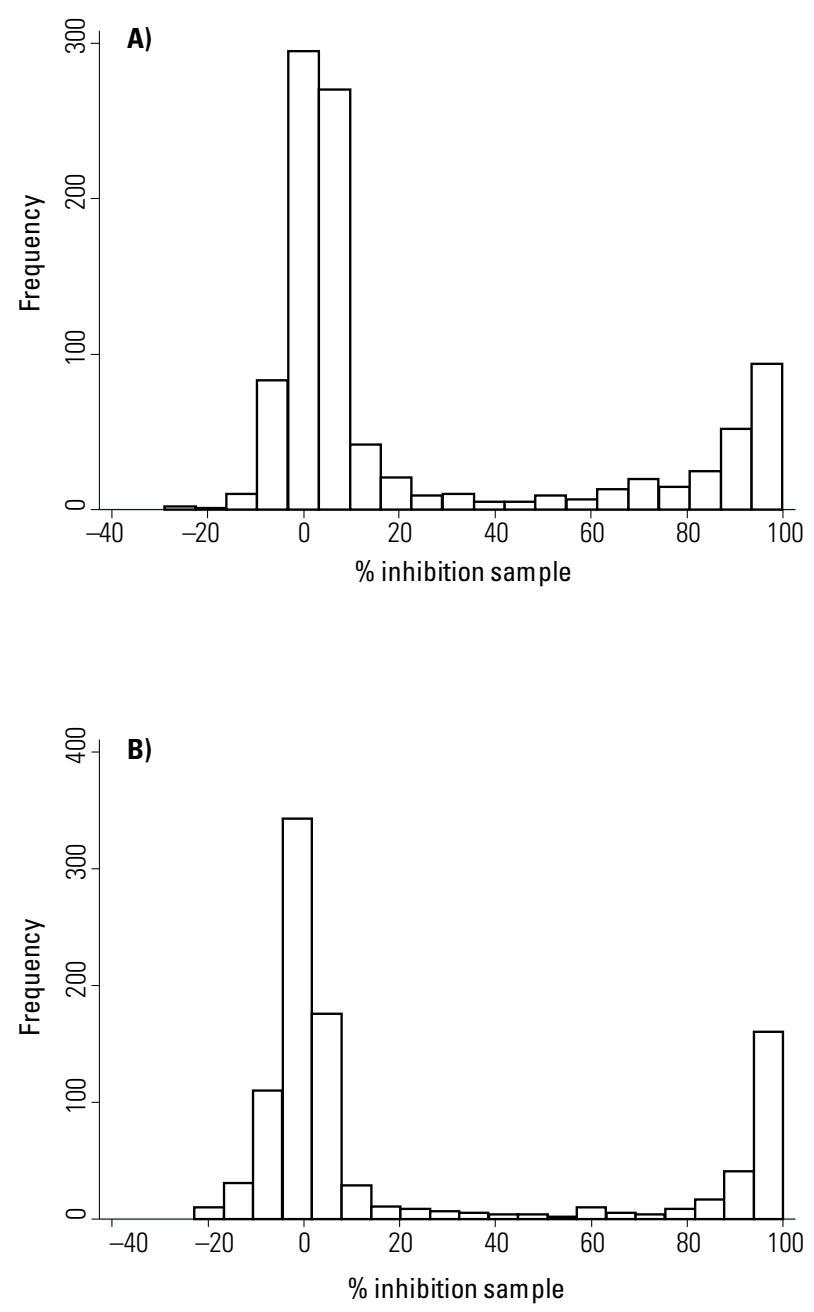

Fig. 1

Figures $A$ and $B$ show frequency histograms of percentage of inhibition for each blocking enzyme-linked immunosorbent assay (ELISA) test and $C$ and $D$ show the corresponding kernel density estimations

ELISA: enzyme-linked immunosorbent assay

$A$ and B: frequency histograms of percentage of inhibition for NS3-blocking ELISA and recombinant E0-blocking ELISA, respectively

$\mathrm{C}$ and D: kernel density estimation for NS3-blocking ELISA and recombinant EO-blocking ELISA, respectively

Percentage of inhibition on the $x$-axis line should be read as -40 to $100 \%$

\section{Estimated true prevalence, test sensitivity and test specificity}

Trace plots suggested that the chains were poorly mixing and the autocorrelation plots indicated that significant autocorrelations were present up to lag 30. Upon thinning with a thinning coefficient of 30 , the model appeared to converge because the chains were properly mixing and the autocorrelations dropped to zero. The BGR plots corroborated these findings. The estimated Bayesian $P$-value of this study's model, 0.478 , indicated no particular problems with model fit. The $\mathrm{pD}$ estimated from the multinomial probabilities in R was 2.43 and the DIC was 21.62. The estimated $\mathrm{pD}$ and DIC based on the authors' model (2.66 and 21.85, respectively) were quite close to the optimal values. The estimated values of the Se and $S p$
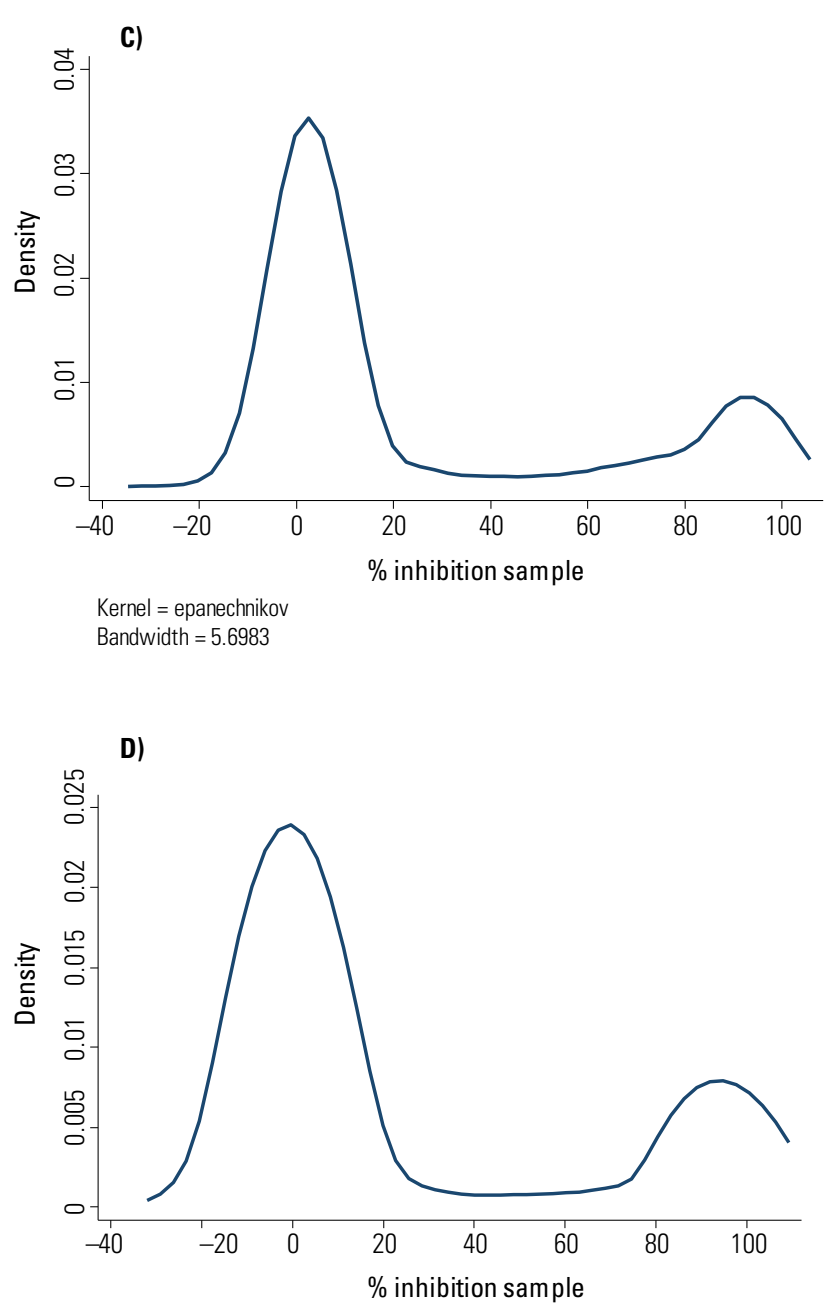

Kernel $=$ epanechnikov Bandwidth $=9.1900$ 
for both NS3- and E0-competitive ELISAs are summarised in Table II.

\section{Table II}

\begin{abstract}
Sensitivity and specificity estimates for non-structural protein NS3-blocking enzyme-linked immunosorbent assay (ELISA) and recombinant envelope glycoprotein E0-blocking ELISA, using a Bayesian approach
\end{abstract}

\begin{tabular}{lllrc}
\hline Scenario & ELISA & Parameter & $\begin{array}{c}\text { Uniform } \\
\text { prior }\end{array}$ & \multicolumn{1}{c}{$\begin{array}{c}\text { Posterior } \\
\text { estimates (Cr. I) }\end{array}$} \\
\hline $\begin{array}{lllrl}\text { Informative } \\
\text { priors }\end{array}$ & NS3-blocking & Prevalence & {$[0.20,0.40]$} & $0.233(0.206-0.262)$ \\
& & Sp (c) & {$[0.95,1]$} & $0.972(0.951-0.998)$ \\
& \multirow{2}{*}{ E0-blocking } & Se & {$[0.95,1]$} & $0.987(0.966-0.999)$ \\
& & Sp & {$[0.95,1]$} & $0.961(0.951-0.977)$ \\
Non- & & Prevalence & {$[0,1]$} & $0.243(0.003-0.988)$ \\
informative \\
priors & \multirow{2}{*}{ NS3-blocking } & Se & {$[0,1]$} & $0.557(0.058-0.975)$ \\
& & Sp & {$[0,1]$} & $0.813(0.381-0.993)$ \\
& E0-blocking & Se & {$[0,1]$} & $0.625(0.106-0.988)$ \\
& & Sp & {$[0,1]$} & $0.790(0.266-0.987)$ \\
\hline
\end{tabular}

Cr. I: credibility interval

ELISA: enzyme-linked immunosorbent assay

Se: Sensitivity

Sp: Specificity

Priors were estimated according to available literature information. Previous study estimated the prevalence of bovine viral diarrhoea virus (BVDV) exposure to be $33 \%$ (8). For sensitivity and specificity of the NS3-blocking ELISA, priors were available $(2,21)$. For sensitivity and specificity of the E0-blocking ELISA, priors were obtained from a surrogate data set because only information based on an E0-indirect ELISA was available (9)

As the outcome, the model also estimated an overall true seroprevalence of BVDV of 23.3\% (95\% credibility interval [Cr I]: 20.6-26.2). The estimated correlation between the two tests within the non-infected population was 0.25 (95\% Cr I: $-0.0026-0.59)$ and for the positive results it was 0.30 (95\% Cr I: $-0.01-0.77$ ). The significant correlations of 0.25 and 0.30 provide evidence that the outcomes of the two tests are correlated for both noninfected and infected animals.

\section{Sensitivity analysis}

An Se analysis was performed using several priors. For each model, validity criteria were assessed (the Bayesian $P$-value, the $\mathrm{pD}$ value, the DIC value and the BGR statistic). The use of non-informative priors for all parameters led to a non-identifiable model due to the absence of convergence. The two extreme selected sets of priors and their corresponding posterior estimates are summarised in Table II. Beside the two extreme sets of priors shown in Table II, other prior distributions were applied and resulted in the absence of an interesting model (data not shown). These models included the following combinations of priors:
- non-informative prior for the seroprevalence and informative priors for the Se and Sp of NS3- and EOcompetitive ELISAs

- non-informative priors for the $\mathrm{Se}$ and $\mathrm{Sp}$ of the NS3-competitive ELISA and informative priors for the seroprevalence and the $\mathrm{Se}$ and $\mathrm{Sp}$ of the E0-competitive ELISA

- non-informative priors for the Se and $\mathrm{Sp}$ of the E0-competitive ELISA and informative priors for the seroprevalence and the Se and Sp of the NS3-competitive ELISA.

\section{Discussion}

The primary objective of this study was to evaluate the diagnostic characteristics of two commercial competitive ELISAs based on the NS3 non-structural protein and the recombinant EO protein of BVDV, using a Bayesian approach. In addition, the results allowed estimation of the seroprevalence of BVDV in young bovines in southern Belgium.

In summary, the Se and Sp were estimated, respectively, as $97.2 \% \quad(95 \% \quad \mathrm{Cr} \quad \mathrm{I}$ : 95.1-99.8) and $98.7 \%$ (95\% Cr I: 96.6-99.9) for the first test (based on the NS3 non-structural protein) and 95.8\% (95\% Cr I: 91.1-99.7) and $96.1 \%$ (95\% Cr I: 95.1-97.7) for the second test (based on the E0 protein). The results obtained with the two tests were not significantly different. In addition, using both ELISAs, the current BVDV exposure among young bovines in southern Belgium was estimated at 23.3\% (95\% Cr I: 20.6-26.2).

By definition, the estimation of the Se and Sp of a diagnostic test requires knowledge of the true disease status of the animals on which the test is applied. This status is given by a 'gold standard' test. In the absence of a 'gold standard' test, a Bayesian approach is helpful to estimate test Se, Sp and prevalence, as has been done for several diseases (19, $20,27,28,29,30)$. This is also the case for estimation of the BVDV prevalence (29). Moreover, the World Assembly of Delegates of the OIE recently added the Bayesian approach to the OIE Manual of Diagnostic Tests and Vaccines for Terrestrial Animals as a tool to estimate the Se and Sp of diagnostic tests (12).

Prior available information on Belgian BVDV prevalence (16) and on the Se and Sp of the NS3competitive ELISA $(2,21)$ were included in the authors' estimation process. For the Se and Sp of the E0-competitive ELISA, priors derived from a surrogate data set were used because information was available only for an indirect ELISA (9). Prior knowledge may reduce the number 
of parameters to be assessed by the model. However, the posterior estimates resulting from the Bayesian analysis will be a combination of the data resulting from both ELISAs and the prior knowledge (30). It has been found that the prior information may influence posterior estimates in the course of the analysis (20). Indeed, in this study, priors were represented by ranges of values (test characteristics) obtained by merging estimates produced in the course of several epidemiological studies (using different conditions and methodologies), and they may not necessarily be relevant to the current situation. Nevertheless, the results obtained from the Se analysis influenced the posterior estimates more than the prior information did. Ultimately, the choice of priors allowed robust results to be obtained. This robustness is important for trade purposes, especially because BVD is a transboundary disease. In situations where prior information on Se and Sp is lacking, it is recommended to use a sufficiently representative sample to accurately estimate the true prevalence and test characteristics. In addition, an Se analysis should be systematically performed.

In addition to the main scope of this paper, the model was used to estimate the true seroprevalence of BVDV in southern Belgium. A relatively low true prevalence (23.3\%) was found when compared with the previously reported true prevalence of $32.9 \%$ estimated by Sarrazin et al. (16) in Belgium. However, comparisons of these results have some limitations related to differences in sampling designs and strategies, and in the ELISAs used. Indeed, several differences exist between the present and the past (16) studies: the study period (2014 in this study versus 2009-2010 in the past study), the area (southern Belgium for this study and Belgium as a whole for the past study), the ELISA (different manufacturers) and the method used for the estimation of prevalence (Bayesian approach based on two ELISAs in the present study versus estimation of true prevalence based on the apparent prevalence and the Se and Sp claimed by the producer and using the Rogan and Gladen formulae [31], for the past study). In addition, in both studies, the true seroprevalence was estimated without differentiating between vaccinated (modified-live vaccines) and naturally infected animals.

The posterior estimates given by the Bayesian model are based on serological test results of the NS3- and E0-competitive ELISAs. Considering the estimates of test characteristics (Table II), the best combination of Se and Sp was obtained for the NS3-competitive ELISA, with a Youden index $(\mathrm{Se}+\mathrm{Sp}-1)$ of 0.96 , followed by the E0-competitive ELISA, with a Youden index of 0.92 (32). The index for both NS3- and E0-competitive ELISAs is similar to the index (0.94) of another commercially available BVDV ELISA (2).

A good level of agreement between the two diagnostic tests was obtained when considering positive results obtained by both ELISAs (97.3\%). Similarly, a significant correlation between the two tests was found for negative results (91.7\%). This could be related to the high Sp of both tests (estimated during the Bayesian analysis for both tests) (Table II) and the good separation between the two subpopulations (BVDV-exposed and unexposed animals) obtained using both tests (especially the E0competitive ELISA) (Fig. 1). This separation seems to be more pronounced than for another commercially available ELISA (2). A good level of agreement has also been reported for tests with high Sp in other diseases (33).

The major immune proteins of BVDV are the envelope glycoproteins E0 and E2 and the non-structural protein NS3 (9). The agreement between ELISAs using these immunogenic proteins and the VNT is considered excellent in the literature (6), in particular for the E2 protein (34). The E0 and NS3 proteins are more conserved among BVDV strains $(10,11)$, allowing in some cases the detection of antibodies that cannot be measured by the VNT with BVDV type 1 but can be detected easily with Western blot (9). A possible explanation for this observation is that the VNT only detects antibodies with neutralising activity, but these antibodies do not represent the total population of antiBVDV antibodies (9). These results highlight that the VNT should not be considered as a gold standard (i.e. a perfect test with Se and Sp equal to 100\%) but as a reference test (with high Se and Sp but not equal to 100\%), and ELISAs based on E0 or NS3 could represent a promising surveillance BVDV diagnostic tool to minimise false-negative serological reactions (9). Indeed, the use of ELISAs (NS3 and E0) that have literature evidence of excellent agreement with the VNT as reference tests certainly contributed to the good estimation of the true prevalence of BVDV in this study. In addition, the NS3 protein is essential for BVDV replication (35) and it is consequently expressed by wild-type as well as live attenuated vaccine virus. Recently, among three commercially available inactivated BVDV vaccines, one did not interfere with the detection of anti-NS3 antibodies in bulk tank milk of vaccinated herds, showing that a putative differentiating infected from vaccinated animals (DIVA) strategy could be implemented (36). In this context, the use of both E0- and NS3-competitive ELISAs could allow discrimination of BVDV-free, naturally infected and vaccinated herds.

Importantly, virological testing of all newborn calves is a valid method for rapidly detecting PI animals, but not for monitoring the BVDV-free status of a herd (37). BVDV surveillance should rely on the combination of virological tests performed systematically on newborn calves and serological tests performed at the herd level (38).

In summary, the results of this study support the use of an ELISA based on the E0 or NS3 protein as an efficient diagnostic tool to be applied in the surveillance of BVDV. Using the two ELISAs in parallel allowed estimation of 
a true prevalence of BVDV of 23.3\% in young bovines in southern Belgium. However, because the use of a live attenuated vaccine cannot be ruled out, the estimated true seroprevalence combines naturally infected as well as vaccinated animals.

\section{Acknowledgements}

The authors thank Bio-X Diagnostics for providing the ELISA kits.

\section{Appendix 1}

\section{WinBugs ${ }^{\circledR}$ code for estimating prevalence and test characteristics of NS3-blocking enzyme-linked immunosorbent assay (ELISA) and EO-blocking ELISA}

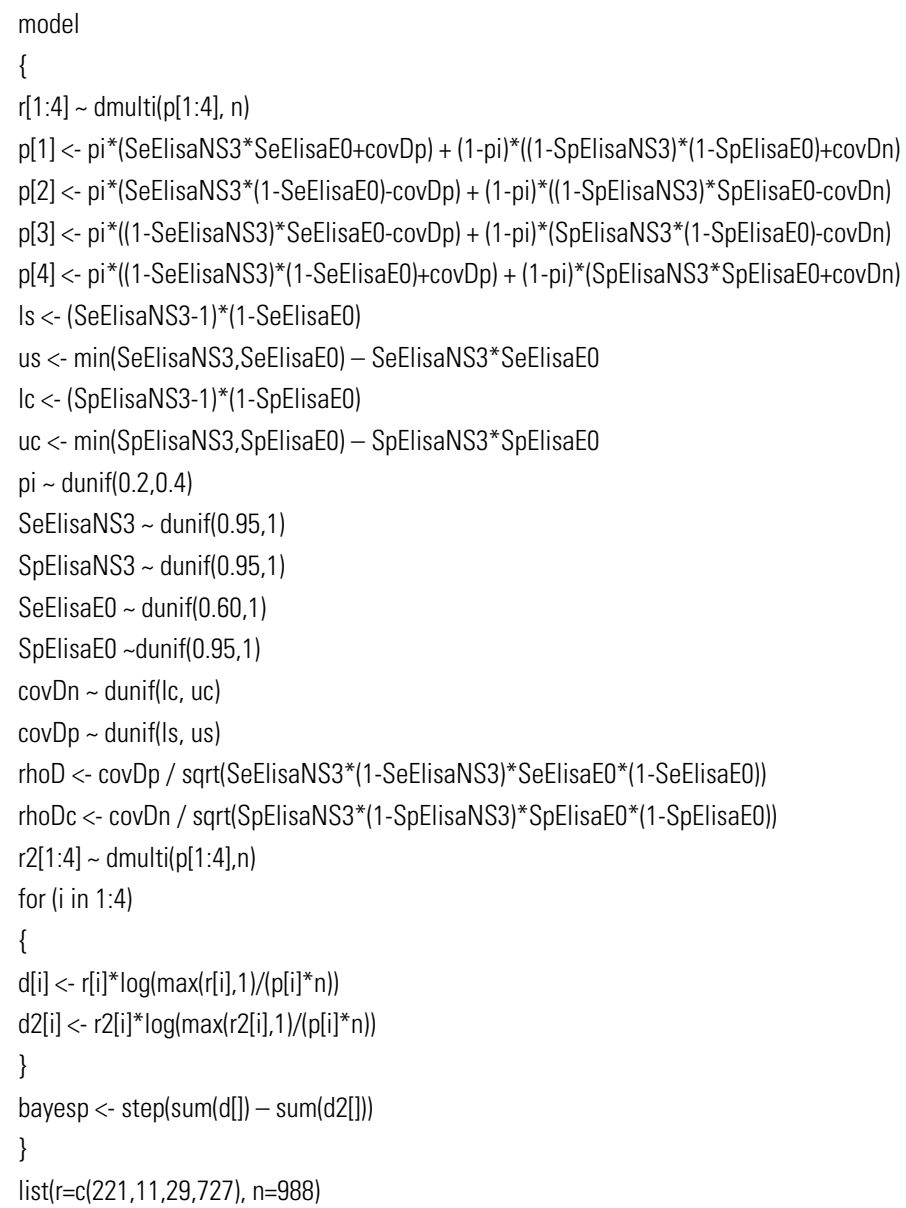




\title{
Analyse bayésienne de deux méthodes immuno-enzymatiques par compétition pour la détection d'anticorps viraux de la diarrhée virale bovine dans les sérums bovins
}

\author{
C. Saegerman, C. Quinet, G. Czaplicki \& F. Dal Pozzo
}

\begin{abstract}
Résumé
Les infections par le virus de la diarrhée virale bovine (VDVB) sont endémiques dans la plupart des pays d'élevage du monde et la diarrhée virale bovine est une maladie transfrontalière. Les éléments d'un programme de contrôle de la VDVB sont la vaccination, la biosécurité, l'élimination d'animaux porteurs d'une infection persistante et la surveillance. L'objectif de cette étude était d'évaluer la sensibilité $(S e)$ et la spécificité $(S p)$ de deux kits commerciaux ELISA (épreuve immuno-enzymatique) par compétition basés sur une sélection de protéines immunodominantes du VDVB, la protéine non structurale NS3 (p80) et la glycoprotéine d'enveloppe recombinante EO (Erns). Les deux kits étaient testés sur des échantillons individuels de sérum collectés de manière aléatoire chez de jeunes bovins dans le sud de la Belgique afin de détecter les anticorps VDVB spécifiques. L'analyse bayésienne montrait une Se de $97,2 \%$ (intervalle de crédibilité de $95 \%$ [ICr] de 95,1 à 99,8) et une Sp de 98,7 (ICr $95 \%$ de 96,6 à 99,9) pour le premier kit et une Se de 95,8 (ICr $95 \%$ de $91,1$ à 99,7$)$ et une $\mathrm{Sp}$ de 96,1 (ICr $95 \%$ de 95,1 à 97,7) pour le deuxième. Les différences n'étaient pas significatives. De même, l'application des deux ELISA montrait que l'exposition actuelle des jeunes bovins du sud de la Belgique au VDVB s'élevait à 23,3 \% (ICr $95 \%$ de 20,6 à 26,2). L'association de tests virologiques effectués chez tous les nouveau-nés afin de détecter des animaux à infection persistante et de tests sérologiques de routine par ELISA chez les jeunes animaux est recommandée pour la surveillance de VDVB.
\end{abstract}

\section{Mots-clés}

Analyse bayésienne - Belgique - Bovins - Diagnostic - ELISA - Évaluation - Sensibilité Spécificité - Virus de la diarrhée virale bovine.

\section{Evaluación bayesiana de dos ensayos inmunoenzimáticos de competición para la detección de anticuerpos contra el virus de la diarrea viral bovina en sueros bovinos}

\author{
C. Saegerman, C. Quinet, G. Czaplicki \& F. Dal Pozzo
}

\begin{abstract}
Resumen
Las infecciones por el virus de la diarrea viral bovina (BVDV), considerada enfermedad transfronteriza, son endémicas en la mayoría de los países del mundo que albergan producción bovina. Los principales elementos de todo programa de lucha contra este virus son la vacunación, la seguridad biológica, la eliminación de los animales con infección persistente y la vigilancia. Los autores describen un estudio encaminado a evaluar la sensibilidad y especificidad de dos ensayos inmunoenzimáticos (ELISA) comerciales basados en sendas
\end{abstract}


proteínas inmunodominantes del virus: la proteína no estructural NS3 (p80) y la glucoproteína recombinante de envoltura EO (Erns). Ambas pruebas fueron aplicadas a sueros procedentes de una muestra aleatoria de bovinos jóvenes del sur de Bélgica con el fin de detectar anticuerpos específicos contra el virus. Empleando un método de estadística bayesiana se calcularon la sensibilidad y la especificidad, que resultaron, respectivamente, de un $97,2 \%$ (intervalo de credibilidad [I Cr] al 95\%: 95,1-99,8) y un 98,7\% (I Cr 95\%: 96,6-99,9) en el caso de la primera prueba y de un $95,8 \%$ (I Cr 95\%: $91,1-99,7$ ) y un $96,1 \%$ (I Cr $95 \%$ : 95,1$97,7)$ en el caso de la segunda. Los resultados obtenidos con una y otra prueba no diferían significativamente entre sí. Además, utilizando ambas técnicas ELISA se calculó que la exposición actual al virus de los bovinos jóvenes del sur de Bélgica se cifraba en un 23,3\% (I Cr 95\%: 20,6-26,2). Para las tareas de vigilancia del BVDV se recomienda combinar el análisis virológico de todos los recién nacidos - para detectar animales con infección persistente - con la realización periódica de pruebas serológicas en el ganado joven con la técnica ELISA.

\section{Palabras clave}

Bélgica - Diagnóstico - ELISA - Ensayo inmunoenzimático - Especificidad - Evaluación - Ganado bovino - Sensibilidad - Sistema bayesiano - Virus de la diarrea viral bovina.

\section{References}

1. Lindberg A., Brownlie J., Gunn G.J., Houe H., Moennig V., Saatkamp H.W., Sandvik T. \& Valle P.S. (2016). - The control of bovine viral diarrhoea virus in Europe: today and in the future. Rev. Sci. Tech. Off. Int. Epiz., 25 (3), 961-979. doi:10.20506/rst.25.3.1703.

2. Lanyon S.R., Anderson M.L., Bergman E. \& Reichel M.P. (2013). - Validation and evaluation of a commercially available ELISA for the detection of antibodies specific to bovine viral diarrhoea virus (bovine pestivirus). Aust. Vet. J., 91 (1-2), 5256. doi:10.1111/j.1751-0813.2012.01010.x.

3. Houe H. (2003). - Economic impact of BVDV infection in dairies. Biologicals, 31 (2), 137-143. doi:10.1016/S10451056(03)00030-7.

4. Mars M.H. \& Van Maanen C. (2005). - Diagnostic assays applied in BVDV control in the Netherlands. Prev. Vet. Med., 72 (1-2), 43-48. doi:10.1016/j.prevetmed.2005.08.005.

5. Sarrazin S., Cay A.B., Laureyns J. \& Dewulf J. (2014). - A survey on biosecurity and management practices in selected Belgian cattle farms. Prev. Vet. Med., 117 (1), 129-139. doi:10.1016/j.prevetmed.2014.07.014

6. Sandvik T. (2005). - Selection and use of laboratory diagnostic assays in BVD control programmes. Prev. Vet. Med., 72 (1-2), 3-16. doi:10.1016/j.prevetmed.2005.08.015.

7. Edwards S. (1990). - The diagnosis of bovine virus diarrhoeamucosal disease in cattle. In Bovine virus diarrhoea. Rev. Sci. Tech. Off. Int. Epiz., 9 (1), 115-130. doi:10.20506/rst.9.1.486.
8. Lindberg A.L. (2003). - Bovine viral diarrhoea virus infections and its control: a review. Vet. Q., 25 (1), 1-16. doi: 10.1080/01652176.2003.9695140.

9. Chimeno Zoth S. \& Taboga O. (2006). - Multiple recombinant ELISA for the detection of bovine viral diarrhoea virus antibodies in cattle sera. J. Virol. Meth., 138 (1-2), 99-108. doi:10.1016/j.jviromet.2006.07.025.

10. Ridpath J.F. (2003). - BVDV genotypes and biotypes: practical implications for diagnosis and control. Biologicals, 31 (2), 127-131. doi:10.1016/S1045-1056(03)00028-9.

11. Ridpath J.F. \& Bolin S.R. (1995). - The genomic sequence of a virulent bovine viral diarrhoea virus (BVDV) from the type 2 genotype: detection of a large genomic insertion in a noncytopathic BVDV. Virology, 212 (1), 39-46. doi:10.1006/ viro.1995.1451.

12. World Organisation for Animal Health (OIE) (2013). Chapter 1.1.6. Principles and methods of validation of diagnostic assays for infectious diseases. In Manual of Diagnostic Tests and Vaccines for Terrestrial Animals. OIE, Paris, France. Available at: www.oie.int/fileadmin/Home/eng/ Health_standards/tahm/1.01.06_VALIDATION.pdf (accessed on 22 January 2018).

13. Moennig V.L., Leder L., Greiser-Wilke I., Frey H.R. \& Liess B. (1991). - A new enzyme immunoassay for the detection of antibodies against the bovine viral diarrhea virus. Tierärztl. Praxis, 19 (1), 35-38. 
14. Paton D.J., Ibata G., Edwards S. \& Wensvoort G. (1991). An ELISA detecting antibody to conserved pestivirus epitopes. J. Virol. Meth., 31 (2-3), 315-324. doi:10.1016/01660934(91)90169-Z.

15. Beaudeau F., Belloc C., Seegers H., Assié S., Sellal E. \& Joly A. (2001). - Evaluation of a blocking ELISA for the detection of bovine viral diarrhoea virus (BVDV) antibodies in serum and milk. Vet. Microbiol., 80 (4), 329-337. doi:10.1016/S03781135(01)00322-4.

16. Sarrazin S., Veldhuis A., Méroc E., Vangeel I., Laureyns J., Dewulf J., Caij A.B., Piepers S., Hooyberghs J., Ribbens S. \& Van Der Stede Y. (2013). - Serological and virological BVDV prevalence and risk factor analysis for herds to be BVDV seropositive in Belgian cattle herds. Prev. Vet. Med., 108 (1), 28-37. doi:10.1016/j.prevetmed.2012.07.005.

17. Petrie A. \& Watson P. (2013). - Statistics for veterinary and animal science, 3rd Ed. Wiley-Blackwell, Oxford, United Kingdom, 414 pp. Available at: www.agrifs.ir/sites/default/ files/Statistics\%20for\%20Veterinary\%20and\%20Animal\% 20Science\%2C\%20Third\%20Edition-www.gkambiz.blogfa. com_.pdf (accessed on 11 May 2018).

18. Berkvens D., Speybroeck N., Praet N., Adel A. \& Lesaffre E. (2006). - Estimating disease prevalence in a Bayesian framework using probabilistic constraints. Epidemiology, 17 (2), 145-153. doi:10.1097/01.ede.0000198422.64801.8d.

19. Branscum A.J., Gardner I.A. \& Johnson W.O. (2005). Estimation of diagnostic-test sensitivity and specificity through Bayesian modeling. Prev. Vet. Med., 68 (2-4), 145163. doi:10.1016/j.prevetmed.2004.12.005.

20. Sanogo M., Thys E., Achi Y.L., Fretin D., Michel P., Abatih E., Berkvens D. \& Saegerman C. (2013). - Bayesian estimation of the true prevalence, sensitivity and specificity of the Rose Bengal and indirect ELISA tests in the diagnosis of bovine brucellosis. Vet. J., 195 (1), 114-120. doi:10.1016/j. tvjl.2012.06.007.

21. Kramps J.A., van Maanen C., van de Wetering G., Stienstra G., Quak S., Brinkhof J., Rønsholt L. \& Nylin B. (1999). - A simple, rapid and reliable enzyme-linked immunosorbent assay for the detection of bovine virus diarrhoea virus (BVDV) specific antibodies in cattle serum, plasma and bulk milk. Vet. Microbiol., 64 (2-3), 135-144. doi:10.1016/S03781135(98)00265-X.

22. Spiegelhalter D.J., Thomas A., Best N. \& Lunn D. (2003). - WinBUGS User manual. Version 1.4, 60 pp. Available at: www.mrc-bsu.cam.ac.uk/wp-content/uploads/manuall4.pdf (accessed on 23 January 2018).

23. R Development Core Team (2016). - R: a language and environment for statistical computing. R Foundation for Statistical Computing, Vienna, Austria. Available at: www. R-project.org/ (accessed on 23 January 2017).

24. Cicchetti D.V. \& Feinstein A.R. (1990). - High agreement but low kappa: II. Resolving the paradoxes. J. Clin. Epidemiol., 43 (6), 551-558. doi:10.1016/0895-4356(90)90159-M.
25. Graham P. \& Bull B. (1998). - Approximate standard errors and confidence intervals for indices of positive and negative agreement. J. Clin. Epidemiol., 51 (9), 763-771. doi:10.1016/ S0895-4356(98)00048-1.

26. Enoe C., Georgiadis M.P. \& Johnson W.O. (2000). - Estimation of sensitivity and specificity of diagnostic tests and disease prevalence when the true disease state is unknown. Prev. Vet. Med., 45 (1-2), 61-81. doi:10.1016/S0167-5877(00)00117-3.

27. Praet N., Dorny P., Saegerman C., Marcotty T. \& Berkvens D. (2006). - Estimation de la prévalence d'une maladie et des caractéristiques des tests diagnostiques par une approche bayésienne. Épidémiol. Santé Anim., 49, 113-130. Available at: http://aeema.vet-alfort.fr/images/2006-49/49.13.pdf (accessed on 15 May 2018).

28. Brochier B., De Blander H., Hanosset R., Berkvens D., Losson B. \& Saegerman C. (2007). - Echinococcus multilocularis and Toxocara canis in urban red foxes (Vulpes vulpes) in Brussels, Belgium. Prev. Vet. Med., 80 (1), 65-73. doi:10.1016/j. prevetmed.2007.01.004.

29. Brülisauer F., Lewis F.I., Ganser A.G., McKendrick I.J. \& Gunn G.J. (2010). - The prevalence of bovine viral diarrhoea virus infection in beef suckler herds in Scotland. Vet. J., 186 (2), 226-231. doi:10.1016/j.tvjl.2009.08.011.

30. Sanogo M., Abatih E. \& Saegerman C. (2014). - Bayesian versus frequentist methods for estimating true prevalence of disease and diagnostic test performance. Vet. J., 202 (2), $204-$ 207. doi:10.1016/j.tvjl.2014.08.002.

31. Rogan W.J. \& Gladen B. (1978). - Estimating prevalence from the results of a screening test. Am. J. Epidemiol., 107 (1), 7176. doi:10.1093/oxfordjournals.aje.a112510.

32. Youden W.J. (1950). - Index for rating diagnostic tests. Cancer, 3 (1), 32-35. doi:10.1002/1097-0142(1950)3:1<32::AIDCNCR2820030106>3.0.CO;2-3.

33. Dohoo I.R., Wright P.F., Ruckerbauer G.M., Samagh B.S., Robertson F.J. \& Forbes L.B. (1986). - A comparison of five serological tests for bovine brucellosis. Can. J. Vet. Res., 50 (4), 485-493. Available at: www.ncbi.nlm.nih.gov/pmc/articles/ PMC1255253/pdf/cjvetres00064-0039.pdf (accessed on 15 May 2018).

34. Franco Mahecha O.L., Ogas Castells M.L., Combessies G., Lavoria M.A., Wilda M., Mansilla F.C., Seki C., Grigera P.R. \& Capozzo A.V. (2011). - Single dilution avidity-blocking ELISA as an alternative to the bovine viral diarrhea virus neutralization test. J. Virol. Meth., 175 (2), 228-235. doi:10.1016/j.jviromet.2011.05.022.

35. Gu B., Liu C., Lin-Goerke J., Maley D.R., Gutshall L.L., Feltenberger C.A. \& Del Vecchio A.M. (2000). - The RNA helicase and nucleotide triphosphatase activities of the bovine viral diarrhea virus NS3 protein are essential for viral replication. J. Virol., 74 (4), 1794-1800. doi:10.1128/ JVI.74.4.1794-1800.2000. 
36. Sayers R.G., Sayers G.P., Graham D.A. \& Arkins S. (2015). - Impact of three inactivated bovine viral diarrhoea virus vaccines on bulk milk p80 (NS3) ELISA test results in dairy herds. Vet. J., 205 (1), 56-61. doi:10.1016/j.tvjl.2015.03.025.

37. Houe H., Lindberg A. \& Moennig V. (2006). - Test strategies in bovine viral diarrhea virus control and eradication campaigns in Europe. J. Vet. Diagn. Invest., 18 (5), 427-436. doi:10.1177/104063870601800501.
38. Laureyns J. (2014). - Challenges in the control of bovine viral diarrhoea virus: implications for a Belgian eradication programme. Doctoral thesis, University of Ghent, Ghent, Belgium, 192 pp. Available at: www.rohh.ugent.be/v3/research/ phd/2014/Laureyns_J.pdf (accessed on 23 January 2018). 